\title{
A Spring without Water: The Conundrum of Anti- Dumping Duties in South African Law
}

\section{Vinti*}

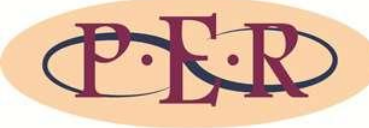

Author

Clive Vinti

Affiliation

University of the Free State, South Africa

Email

vintic@ufs.ac.za

Date published 31 August 2016

Editor Prof C Rautenbach

How to cite this article

Vinti C "A Spring without Water: The Conundrum of Anti-Dumping Duties in South African Law" PER/PELJ 2016(19) - DOI http://dx.doi.org/10.17159/17273781/2016/v19i0a723

Copyright

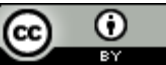

DOI

http://dx.doi.org/10.17159/17273781/2016/v19i0a723

\begin{abstract}
The Agreement on the Implementation of Article VI of the General Agreement on Tariffs and Trade (1994) (Anti-Dumping Agreement) permits the imposition of anti-dumping duties for as long and to the extent necessary to counteract dumping which is causing injury, subject to the proviso that they must be terminated after five years unless a sunset review has been initiated. A sunset review has the purpose of either permitting or terminating the continuation of an anti-dumping duty. This is significant because if the sunset review is not initiated prior to the expiry of the five-year period, the anti-dumping duties will be terminated.
\end{abstract}

Therefore, this places an emphasis on the determination of the precise date of commencement of the anti-dumping duties. This is because an incorrect determination of the date of the imposition of the anti-dumping duty has obvious financial implications for the interested parties. The Supreme Court of Appeal in South Africa has delivered two salient judgments in this regard: firstly, in Progress Office Machines CC $v$ SARS 20082 SA 13 (SCA) (POM), and then more recently, in Association of Meat Importers v ITAC 20134 All SA 253 (SCA) (AMIE).

This paper contends that these two judgments are in conflict and are riddled with inconsistencies. Secondly, the paper contends that the SCA has in the recent AMIE case virtually rewritten its earlier judgment of Progress Office Machines. Lastly, the paper shows that the approach of South African courts to whether the Anti-Dumping Agreement is binding on South African law is fraught with uncertainty and ambivalence. The case analysis also reflects on the impact of the newly minted but yet to be implemented Customs Duty Act with a view to assessing the impact of the new legislation on the issues currently plaguing the anti-dumping regime of South Africa.

\section{Keywords}

Dumping; imposition; provisional payments; publication; sunset review; anti-dumping duty; ratification. 


\section{Introduction}

The General Agreement on Tariffs and Trade (1994) (GATT) works in tandem with the Agreement on the Implementation of Article VI of the General Agreement on Tariffs and Trade (1994) (Anti-Dumping Agreement or ADA), to regulate the practice of "dumping". "Dumping" is defined as the introduction of a product into the commerce of another country at below the normal prices. ${ }^{1}$ The GATT permits the imposition of anti-dumping duties on the "dumped" products. ${ }^{2}$ The anti-dumping duty is calculated based on the "margin of dumping": that is, the difference between the price of the "dumped" product and the "normal price" of the product. ${ }^{3}$

South Africa is a member of the World Trade Organisation (WTO). Its international obligations on tariffs and trade arise from the Anti-Dumping Agreement. ${ }^{4}$ South Africa has promulgated the Customs and Excise Act (the CEA), ${ }^{5}$ the International Trade Administration Act (the ITAA) ${ }^{6}$ and the International Trade Administration Commission Regulations on AntiDumping in South Africa (hereafter, the Regulations), ${ }^{7}$ which are all read together to give effect to the Anti-Dumping Agreement. ${ }^{8}$ However, South Africa is in the process of rewriting its customs legislation to bring it into line with international standards.

* Clive Vinti. LLB (cum laude) (University of Fort Hare); LLM (University of Cape Town). Lecturer, Department of Public Law, University of the Free State. E-mail: vintic@ufs.ac.za. This paper was originally presented at the North West University Conference on Critical Law and Governance Perspectives on Food Security in South Africa: Exploring the Role of Policy-Makers and Other Stakeholders, in July 2015.

1 Article VI of the General Agreement on Tariffs and Trade (1994) (hereafter GATT). Furthermore, A VI of the GATT read with Aa 2 and 3 of the Agreement on the Implementation of Article VI of the General Agreement on Tariffs and Trade (1994) (Anti-Dumping Agreement) (hereafter ADA) provides that the aggrieved party must prove the following: Firstly, the importing country must prove that the product is being sold at a price lower than the normal value; secondly, the dumped product must be a like "product"; thirdly, there must be a threat to or a material injury to or the retardation of the establishment of a domestic industry; and lastly, there must be a causal link between the dumped imports and the alleged injury.

2 Article VI of the GATT.

3 Regulation 12(1) in GN 3197 in GG 25684 of 14 November 2003. See also A 2.2 of the ADA.

4 International Trade Administration Commission v SCAW South Africa (Pty) Ltd 2012 4 SA 618 (CC) (hereafter SCAW).

5 Customs and Excise Act 91 of 1964 (hereafter CEA).

6 International Trade Administration Act 71 of 2002 (hereafter ITAA).

7 GN 3197 in GG 25684 of 14 November 2003 (International Trade Administration Commission Regulations on Anti-Dumping in South Africa) (hereafter the Regulations).

8 SCAW para 2. The court also holds in para 25 that Parliament ratified South Africa's membership of the WTO on 2 December 1994 and approved the ADA on 6 April 1995. 
Consequently, the CEA will be replaced by the Customs Duty Act ${ }^{9}$ (hereafter the CDA). The CDA will become the primary statute regulating dumping in South Africa on a date yet to be determined by the President. ${ }^{10}$ Because of delays in the commencement and implementation of the CDA, this paper will proceed on the premise that the CEA is still the primary legislation regulating dumping in South Africa and the analysis of the case law below will be based on this premise.

Essentially, the ADA provides that the anti-dumping duties must terminate after five years unless a sunset review occurs that permits the continuation of the duty until the review is finalised: at which point the duty will either be terminated or will continue. ${ }^{11}$ As submitted earlier, in order to honour its obligations under the ADA, South Africa promulgated the Regulations. These Regulations were meant to mimic the ADA. ${ }^{12}$ In line with the ADA, Regulation 38.1 provides that definitive anti-dumping duties will remain in place for a period of five years from the date of the publication of the Commission's final recommendation unless otherwise specified or unless reviewed prior to the lapse of the five-year period. Building on this, Regulation 53.1 provides that anti-dumping duties shall remain in place for a period not exceeding five years from the imposition or the last review thereof. Thus, Regulation 38 functions to introduce a default period of five years at the start of the anti-dumping duty whereas Regulation 53 terminates an anti-dumping duty that purports to endure beyond that period. ${ }^{13}$

However, the CEA also creates a necessary yet amorphous wrinkle through the instrument of "provisional payments". ${ }^{14}$ Provisional payments are imposed during the period when the International Trade Administration Commission (ITAC) is investigating the imposition of anti-dumping duties. ${ }^{15}$ ITAC is the official institution mandated with investigating the practice of dumping in South Africa. ${ }^{16}$ The provisional payment is regarded as "security" on goods subject to it and may be retrospectively imposed. ${ }^{17}$ In the same vein, the ADA provides for the imposition of "provisional measures", which may take the form of provisional duties or security after

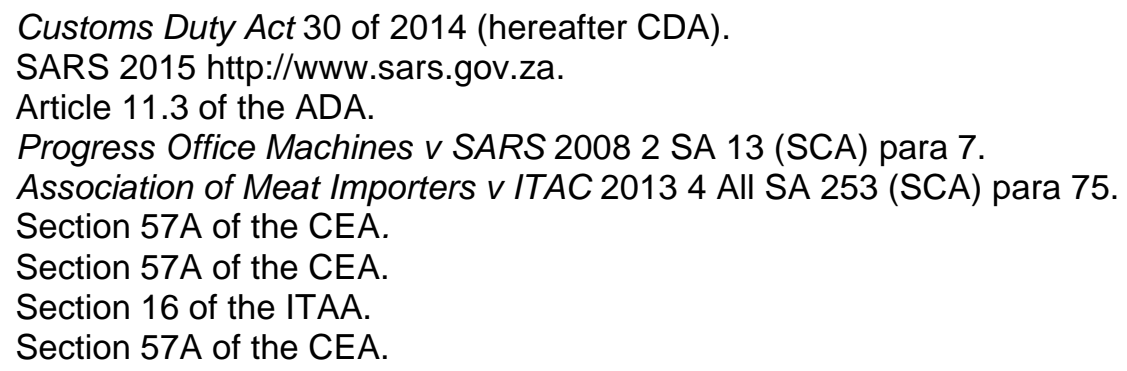


a preliminary affirmative determination has been made of the dumping and the consequent injury to a domestic industry. ${ }^{18}$ This issue could trigger legal disputes for the interested persons because the specific date on which the duties are imposed must be calculated accurately, lest the duties endure beyond what is legally justifiable. This is particularly significant because the courts in South Africa lean towards disregarding the date from which the provisional payments are imposed in the determination of the overall period of operation of the anti-dumping duties.

To this end, the Supreme Court of Appeal (SCA) has delivered two significant judgments: firstly in Progress Office Machines $v$ the South African Revenue Service ${ }^{19}$ (POM hereafter) and then more recently, in Association of Meat Importers $v$ ITAC (AMIE hereafter)..$^{20}$ These two cases hinge on the interpretation of the date of the "imposition" of definitive antidumping duties, particularly where provisional measures are involved, which invariably determine the date of expiry of the duties as espoused by Regulations 38 and 53 of the Regulations.

Consequently, this paper elucidates the method of determining the date of the commencement of anti-dumping duties through a detailed analysis of the AMIE and POM cases, together with the relevant legislation. This paper contends that these two judgments are in conflict and are riddled with inconsistencies. Secondly, the paper contends that the SCA has in the recent AMIE case virtually rewritten its earlier judgment of Progress Office Machines. Lastly, the paper reflects on the South African courts' approach to the ADA, and it is found that the approach is fraught with uncertainty and ambivalence. In a bid to offer a holistic view, the paper also reflects on the impact of the CDA with a view to assessing the impact of the new legislation on the issues currently plaguing the anti-dumping regime of South Africa.

\section{Factual background}

In South African law, if there is evidence that dumping is occurring, ITAC will recommend to the Minister of Trade and Industry to impose the duty. ${ }^{21}$ If the Minister of Trade and Industry accepts the report and recommendations of the ITAC, he can request the Minister of Finance to

\footnotetext{
Articles 7.2 and 5 of the ADA.

Progress Office Machines v SARS 20082 SA 13 (SCA).

Association of Meat Importers v ITAC 20134 All SA 253 (SCA).

Section 16 of the ITAA.
} 
amend Schedule 2 appropriately, which the Minister of Finance is permitted to do by notice in the Government Gazette. ${ }^{22}$

In $A M I E$, three anti-dumping duties had been imposed by the amendment of Schedule 2 before the ITAC came into effect. ${ }^{23}$ For the sake of convenience this paper will focus on the anti-dumping duty imposed on chicken meat portions from the United States of America. ${ }^{24}$ An investigation on anti-dumping against US poultry had been initiated and provisional payment was imposed on 5 July 2000. ${ }^{25}$ The anti-dumping duty was introduced into Schedule 2 with effect from that date by notice in the Government Gazette on 27 December 2000.26 It is immediately apparent that the date of the imposition of the provisional payment and that of the definitive anti-dumping duty differ.

The duty in Progress Office Machines was imposed on paper products imported from Indonesia, by notice in the Government Gazette on 28 May 1999, with retrospective effect to 27 November 1998. ${ }^{27}$ The approach of the authorities here differs from that in AMIE because the authorities in the $P O M$ case had made a deliberate effort to ensure that the date of imposition of the provisional payment correlated with the date of imposition of the definitive anti-dumping duty.

\section{A critique of the SCA's approach on anti-dumping disputes}

\subsection{The "date of publication" theory}

The central legal issue in both AMIE and POM is the method of determining the date when the definitive anti-dumping duties commence and the date when they terminate, particularly where provisional payments are involved. It was contended in AMIE by the authorities that if duties have been terminated, which was interpreted to mean the duties ceased to exist, ${ }^{28}$ they terminated via Article 11.3 of the ADA directly or indirectly or by operation of law. ${ }^{29}$ The court in AMIE held that the mere existence of the duties on the Schedule served as a record of the existence of the

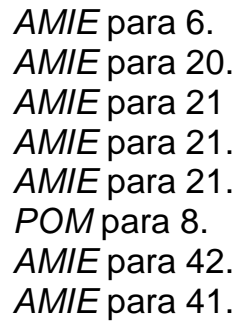


duties. ${ }^{30}$ Thus the duties were held to have been brought into existence by an act of the Minister of Finance in publishing the amendment to the Schedule. ${ }^{31}$ This espouses the "date of publication" theory.

However, in POM, the date of publication theory had been rejected. The Supreme Court of Appeal held that the date of the imposition of the antidumping duty was 27 November 1998, as the "burden" of the duty took effect on that day. ${ }^{32}$ This date correlates with the date upon which the provisional payments were imposed. Therefore, this denotes that the provisional payments and definitive anti-dumping duties are the same species. Secondly, POM holds that based on section 57A (3) of the Act, the duty was fully effective on 27 November $1998 .{ }^{33}$ In fact, in AMIE it was held that the Minister when amending Schedule 2 is entitled to antedate the duty to the date on which the provisional payment was imposed. ${ }^{34}$ Thus there is clear legal provision to antedate the date of the imposition of a definitive anti-dumping duty to correlate with the date of the imposition of the provisional payment, presumably to avoid the unfair consequences of having duties that endure beyond what is legally justifiable.

The implication of $P O M$ is that the purpose of amending Schedule 2 by the Minister of Finance was merely to record the duty which would have already commenced from the date on which the provisional payment was imposed. That is to say, the duty commences on the retrospective date. This would then mean that the sunset review which was conducted after the 5 year period had lapsed in both AMIE and POM was an exercise in futility. On this rationale, the publication of the duties is not crucial to the commencement of the anti-dumping duties. This approach accords with logic and the Anti-Dumping Regulations as constituted at the time.

This is perhaps the reason why there was a proposal to amend the Regulations in South Africa to reflect the date of publication theory as postulated in AMIE. ${ }^{35}$ The court in AMIE proffers the same suggestion. ${ }^{36}$ Despite the proposed amendments to the Regulations, which were meant

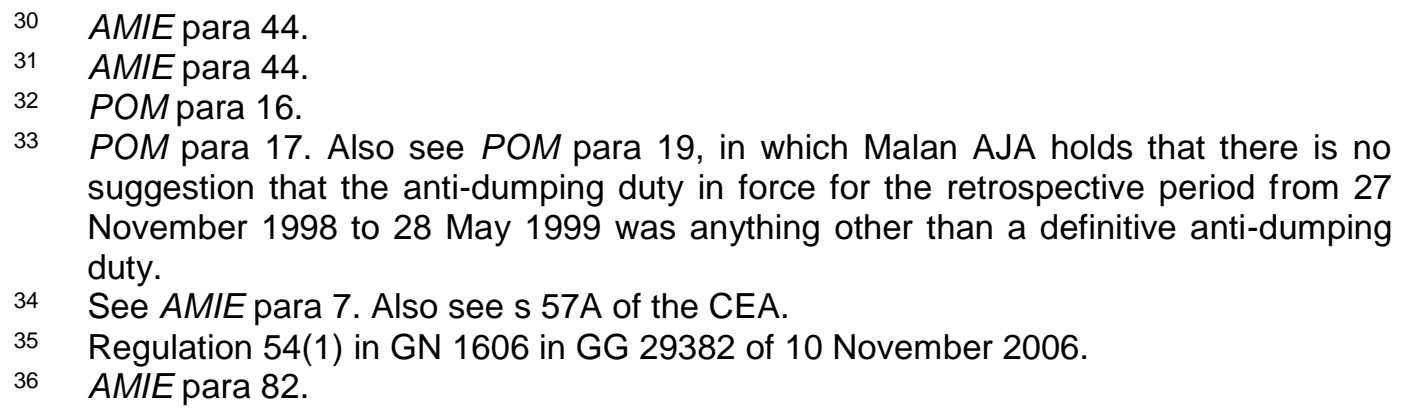
suggestion that the anti-dumping duty in force for the retrospective period from 27 November 1998 to 28 May 1999 was anything other than a definitive anti-dumping duty.

34 See AMIE para 7. Also see $s$ 57A of the CEA.

35 Regulation 54(1) in GN 1606 in GG 29382 of 10 November 2006.

$36 \quad$ AMIE para 82. 
to create clarity on dumping, ${ }^{37}$ South African courts do not seem to understand the issue of dumping with sufficient certainty, nor can they interpret the Regulations correctly. 38

Ironically, the SCA in AMIE held that its interpretation of the Regulations does not mean that South Africa is in breach of its obligations under Article 11.3 of the Anti-Dumping Agreement. ${ }^{39}$ In order to justify their rationale, the court in AMIE attempts unsuccessfully to restrict the ambit of Progress Office Machines to the application of Article 11.3 domestically. ${ }^{40}$ This implies that the AMIE decision is wrong in law according to the Regulations pertaining at the time. In fact, one can go so far as to say that the proposed amendment of the Regulations is a way through which the executive could validate the SCA decision by legitimising duties which in law had expired.

In addition, the court in AMIE ambiguously endorses the decision in POM on the duration of duties. ${ }^{41}$ This creates uncertainty as to what the legal position is on the actual duration of duties. Brink contends that in practice, in South Africa, when anti-dumping duties are imposed with retrospective effect, the total duration of the duties exceeds five years. ${ }^{42}$

Clarity may come from the recently passed, albeit yet to be implemented, Customs Duty Act. The CDA, though silent on the actual duration of an anti-dumping duty, provides that a provisional anti-dumping duty is imposed by notice in the Gazette and takes effect on a date specified in the notice, which may be a date before, on or after the date of publication of that notice. ${ }^{43}$ This spells an end to the contentious date of publication theory and uses a common sense approach that provides the regulatory authorities with the flexibility to choose an appropriate date. The common sense approach of section 15 of the CDA is commendable and negates the type of disputes discussed in this paper as the authorities will be able to choose an appropriate date that allows for the duties to lapse when the 5-year period mandated by the Regulations and the ADA lapses, unless re-authorised by a sunset review. This would bring the South African dumping regulatory framework into line with international law and practice. Thus Section 15 enables the alignment of Regulations 38.1 and 51.1, as

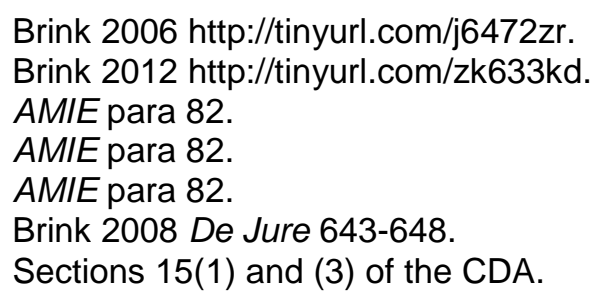


done by the authorities in $P O M$, in order to avoid the problems experienced in AMIE.

Furthermore, section 15(3) of the CDA is significant in two respects: firstly, it is a departure from the CEA in that it explicitly requires the publication of the said notice. Secondly, the CDA reiterates the CEA in that it also provides for the ante-dating of the provisional anti-dumping duty and requires that such a date be specifically provided for in the said notice in the Gazette.

\subsection{The date of the "imposition" of provisional payments}

A "provisional payment" is "security for any anti-dumping duty which may be retrospectively imposed" and may be set off against the amount of any retrospective anti-dumping duty payable. ${ }^{44}$ In $A M I E$ the provisional payment was imposed on 5 July 2000, ${ }^{45}$ whereas in Progress Office Machines it was common cause that the Minister of Finance had imposed the definitive anti-dumping duty on 28 May 1999 with retrospective effect to 27 November $1998 .{ }^{46}$ This denotes that in Progress Office Machines the Minister aligned the date of the imposition of the definitive anti-dumping duty with that of the provisional payment, which had been imposed with effect from 27 November 1998. ${ }^{47}$ The effect of this determination is that the duties would terminate five years from 27 November 1998 unless a sunset review was initiated prior to the expiry of the five-year period. Consequently, the court ruled that the duties in question had lapsed, because the sunset review had occurred more than five years after the anti-duties were imposed.

Secondly; Progress Office Machines' approach implies that the provisional payment represents an anti-dumping duty in the interim, pending a final determination by the investigating authority. This view accords with the ADA, which provides that provisional measures may take the form of a "duty or security by cash or deposit". ${ }^{48}$ This approach is emphatically endorsed by the Panel in Mexico - Anti-Dumping Investigation of High Fructose Corn Syrup from the United States (Mexico Corn Syrup hereafter), which expressly equates "provisional anti-dumping duties" to "provisional measures" under circumstances rather similar to those of the

\footnotetext{
44 Sections 55-57A(3) of the CEA. In this regard also see POM para 4. Also see Reg 33 of the Regulations. In this regard also see A 9.3.2 of ADA.

45 AMIE para 21.

$46 \quad P O M$ para 4.

$47 \quad$ POM para 4.

48 Article 7.2 of the ADA.
} 
cases in question. ${ }^{49}$ Even more significantly, Mexico Corn Syrup establishes that the period of time for which a provisional payment is imposed is generally determinative of the period during which a definitive anti-dumping duty is levied retroactively. ${ }^{50}$ This approach endorses the decision and methodology employed in POM.

Furthermore, in $P O M$ it was established that it is only where a provisional payment has been imposed that the Minister of Finance may impose a definitive anti-dumping duty retrospectively. ${ }^{51}$ It was common cause that the Minister of Finance had imposed the definitive anti-dumping duty on 28 May 1999 "with retrospective effect to 27 November 1998". 52 Significantly, the Panel in Mexico Corn Syrup held that provisional measures constitute the basis under which a Member may impose definitive anti-dumping duties retroactively. ${ }^{53}$

Thirdly; the set-off provision in the CEA establishes a clear and direct relationship between provisional payments and definitive anti-dumping duties. ${ }^{54}$ It can conceivably be argued that the provisional payment is the equivalent of an anti-dumping duty as espoused by the ADA in Article 10.3. This approach is also endorsed by the Panel Report in Mexico Corn Syrup, which holds that a claim regarding the duration of the provisional measures relates to the definitive anti-dumping duty. ${ }^{55}$

In tandem with Mexico Corn Syrup, section 55(2) (b) of the CEA permits the imposition an anti-dumping duty with effect from the date on which any provisional payment is imposed under section 57A. ${ }^{56}$ The effect of this section and its corollary, Article 7.2 of the ADA, is that the date of commencement of the anti-dumping duty is in fact the date on which the provisional payment is imposed.

However, the court in AMIE held that the term "provisional measures" is superfluous in the regulations, as the provisional measures that have been chosen are not a "provisional duty" but instead "security" for an ante-dated duty. ${ }^{57}$ Ndlovu agrees with the rationale of AMIE and expresses the opinion that despite the fact that it may sound unfair, the five-year period

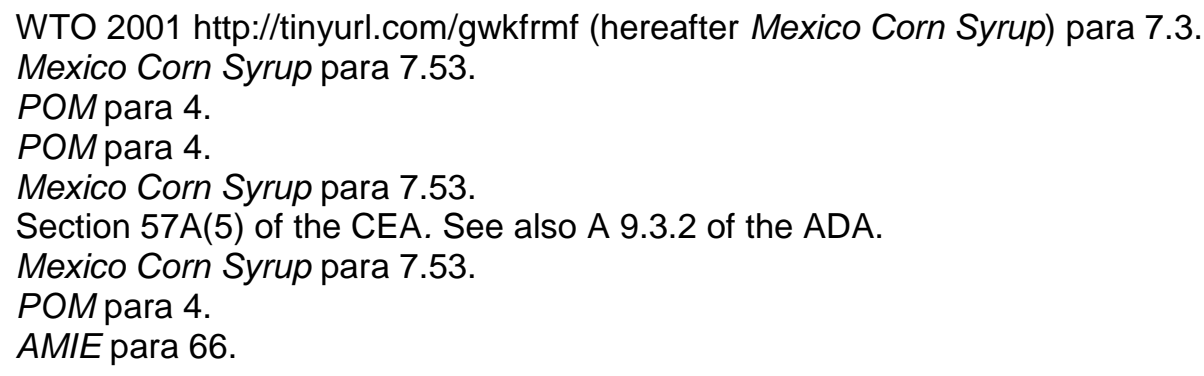


of the duty excludes the period during which provisional duties are imposed. ${ }^{58}$ This approach is problematic: firstly, the word "definitive" implies that there is a situation prior to the present when the duties are "provisional", and secondly, Article 7.2 of the ADA explicitly provides that provisional measures may take the form of "provisional duties" or "security". It follows therefore that the court's differentiation between "provisional measures" and "security" is superficial as it contradicts the reasonable interpretation proffered by international law as per section 233 of the Constitution of the Republic of South Africa, 1996 (hereafter the Constitution). The same court did acknowledge that the Regulations are borrowed from the ADA. It follows then that the arbitrary retort that the provisional duty date of imposition is immaterial to the calculation of the date of commencement of anti-dumping duties is unsound.

Contrary to POM, the same court held in AMIE that the word "imposition" viewed in isolation is quite capable of meaning the date upon which liability for the payment of duties came into being, which is taken to be when the ante-dated liability arose by amendment to Schedule 2,59 contrary to what was found to be the case in $P O M$, which had held that the date of the imposition of the anti-dumping duty was 27 November 1998, as the "burden" of the duty took effect on that day. ${ }^{60}$ The decision in POM is correct because the word "liability" implies a financial obligation to pay, and this is logically triggered by the imposition of provisional payments. It would lead to inequitable results if the "liability" were deemed to be incurred only upon the date of the amendment of Schedule 2 as per the rationale of $A M I E$.

The rationale of the court in AMIE is that words must be construed in their context and in the language of the Regulations: thus if meaning of "imposition" is clear as provided in the Regulations, then that is the meaning it must be given even if it conflicts with what is provided to be the meaning of the word in Article 11.3 of the ADA. ${ }^{61}$ This is astounding, because the same court had conceded on numerous occasions, in the same judgment, that it is careful not to be in conflict with the ADA. 62

The court in AMIE held further that the default period in Regulation 38.1 commences on the date of publication of ITAC's final recommendation,

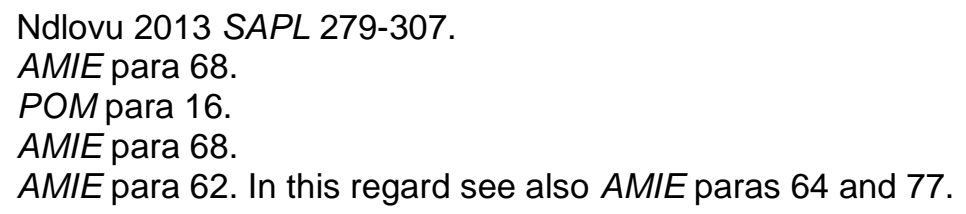


despite the fact that neither the Regulations nor the CEA require publication. ${ }^{63}$ This is taken to have been implied by the Regulations 38.1 and would also be consistent with the ADA. ${ }^{64}$ Publication is said to occur when the Minister Finance or Minister of Trade and Industry introduces or continues an anti-dumping duty by their respective notices in the Gazette. If that is so, the periods in Regulations 38 and 53 would coincide. ${ }^{65}$

Further to this, if Regulation 38.1 required independent publication by ITAC, that would always occur before the respective notices of the Ministers were published and the effect of that would be that the default period of Regulation 38.1 would expire before the guillotine came down in Regulation 53.1.66 To take it a step further, it is held in AMIE that if the date of "imposition" for the purposes of Regulation 53.1 is the ante-date from which there is a liability, the regulation would be blatantly inconsistent with Regulation 38.1, as the default period in Regulation 38.1 would always exceed the maximum period of its existence under Regulation 53.1. The SCA then held in AMIE that the only sensible construction that brings about consistency is if the term "imposition" in Regulation 53 means the date upon which Schedule 2 is amended by notice in the Gazette. ${ }^{67}$ The court in AMIE also held that that determination would not mean that South Africa would be in breach of its obligations under Article 11.3 of the WTO Agreement. ${ }^{68}$ This is perplexing because in the same judgment the court held that Article 11.3 does not apply to South Africa. ${ }^{69}$ It is this ambivalent approach to the ADA that undermines the credibility of both judgments.

The CDA delivers the much-need respite in the debate by introducing simpler terminology and clarifying the method of determining the date of commencement of anti-dumping duties as well as explicitly confirming the nexus between "provisional measures" and the "definitive anti-dumping duties". According to the CDA, the Commissioner can impose a "provisional anti-dumping duty" by notice in the Gazette. ${ }^{70}$ Thus, the CDA replaces the ambiguous instrument of "provisional measures" provided for by the CEA, with that of "provisional anti-dumping duties".

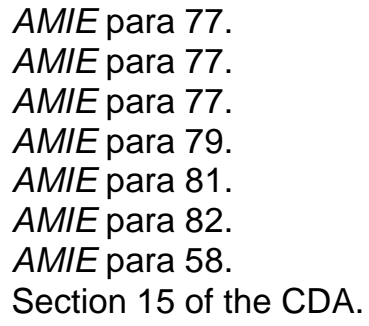


Fundamentally, section 15(1) of the CDA also makes it clear that the provisional anti-dumping duty must be imposed for such a period as the Commission may require. Building on that, section 15(5) of the CDA offers the most illuminating solution to the determination of the question of whether or not the period during which the provisional duty is imposed must be taken into consideration when calculating the total period for the duration of the definitive anti-dumping duty: according to section 15(5), a provisional anti-dumping duty will lapse at the end of the period for which it was imposed unless "that" duty is before the end of that period definitively imposed on those goods in the Customs Tariff. This is significant in two respects: firstly, this sub- section implies that the provisional anti-dumping duty and the definitive anti-dumping duty are the same species and secondly, the sub-section makes it clear that the definitive anti-dumping duty is not a new duty but in fact, "that provisional duty" which is already in application, which then becomes definitively imposed. Thus, there is a nexus between the provisional anti-dumping duty and the definitive antidumping duties. This means that the time period imposed for the provisional anti-dumping duty should be considered in the determination of the total duration of the anti-dumping duty. That explains why in section 15(6) of the CDA the statute provides for off-setting if a person made a payment of the provisional duty at a rate which exceeds the rate of the duty definitively imposed.

Consequently, the CDA endorses the decision in POM as the correct precedent on this issue. Thus, it can be argued that in future the period of an anti-dumping duty should be calculated as encompassing the period during which the provisional anti-dumping duty is in operation. This common sense approach of the CDA is in accordance with the ADA and section 233 of the Constitution.

\subsection{Back tracking of the SCA}

\subsubsection{The central legal issue in Progress Office Machines}

The court in AMIE explains Progress Office Machine's decision and outlines the implications of that judgment. This was done in an attempt to set the record straight, as it were. The court held that POM had little bearing on the matter other than to explain its genesis. ${ }^{71}$ The rationale of the court in AMIE is that POM decided on the meaning of the word "imposition" on the basis of Article 11.3 of the ADA because that is what

$71 \quad$ AMIE para 61. 
the litigants agreed to do. ${ }^{72}$ According to the AMIE judgment, that interpretation of "imposition" is relevant only when the meaning of "imposition" within Regulation 53 is uncertain. ${ }^{73}$ Only then would POM be relevant to the AMIE case, and this is because of section 233 of the Constitution, which requires that the courts prefer a reasonable interpretation of legislation that is consistent with the one given to it in the ADA. ${ }^{74}$ The court then holds that since the validity of the Regulations is not in question, $P O M$ is thus not relevant to $A M I E .^{75}$

This view is incorrect: in $P O M$, the central legal issue in the words of that court was the determination of the commencement date of the five-year period according to South African legislation. ${ }^{76}$ This was held to be so because the ADA has not been enacted into SA law, and thus no rights could be derived from it. ${ }^{77}$ The court made it clear that despite the fact that South Africa passed the ITAA and the Regulations, these are indicative only of an intention to give effect to international treaties such as ADA. The text that had to be interpreted remained South African legislation and its construction must be in conformity with section 233 of the Constitution. ${ }^{78}$ Thus Article 11.3 became relevant through section 233 of the Constitution, which requires that when interpreting the Constitution, every court must prefer any reasonable interpretation of legislation that conforms to international law over any alternative that is inconsistent with international law.

It is contended that this is essentially the same issue that was before the SCA in the AMIE case. According to the language of that court in AMIE, the question before the court was whether the period of five years commenced on the date of the notice or on the date on which the amendment was to have retrospective effect. ${ }^{79}$ In fact, the SCA held that the appeal in AMIE was to overcome the effect of the decision in POM. ${ }^{80}$ The only difference is that POM chose to abide by the courts' constitutional obligations in section 233 whereas the same court in AMIE flouted its constitutional obligations and decided that the principle of construction, that legislation must be construed in favour of consistency

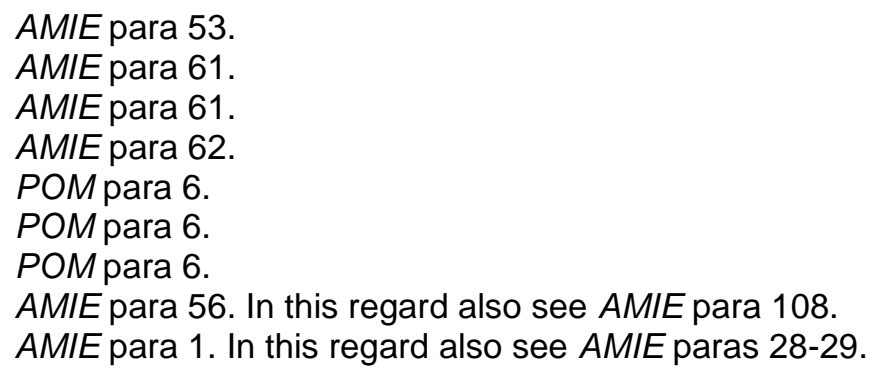


and against inconsistency if the language allows it, trumps its constitutional obligations. ${ }^{81}$

The issue of adherence to section 233 of the Constitution in both cases ought to be read in the light of the debate on transformative justice in South Africa. Former Chief Justice Pius Langa is of the opinion that the role of the courts in a transformative legal order such as South Africa is to justify their decisions with reference to ideas and values enshrined in the Constitution. ${ }^{82}$ This is one of the issues upon which POM and AMIE digress. This is because in the latter decision of AMIE, the SCA deviates from its role in a transformative legal order by deciding that a rule of interpretation based in common law trumps a value explicitly enshrined in the Constitution.

However, Langa submits that although it is true that the law and politics are not the same, they are intertwined, and this means that the notion of the neutral judge must be rejected, as beliefs, opinions and ideas play a role in judicial decisions. ${ }^{83}$ This implies that judges sometimes will make decisions that accord with the politics of the time and that lend themselves to reasons of efficacy and expediency. That is to say, it would cause a financial debacle and a regulatory nightmare if the decision in $P O M$ were allowed to endure, as it essentially invalidated the SA anti-dumping regulatory framework in toto and meant that injurious dumping could occur without any remedy. Thus, the decision in AMIE may have been driven more by reasons of logic and efficacy rather than by pure law, as it were. The court in AMIE conceded as much when it held that the authorities feared that based on the rationale of Progress Office Machines, other duties pertaining at the time may have lapsed, and to overcome the difficulties that would arise the authorities commenced proceedings in the North Gauteng High Court. ${ }^{84}$ This rationale accords with the legal philosophy of American Realism, which propagates the notion that judicial decisions are purely a reflection of the interplay between the law and a judge's backgrounds and personal beliefs.

\subsubsection{Deference to the litigants}

Another factor worth mentioning is the perplexing approach of the SCA to the litigants in both judgments. The SCA defers to the interpretation of the

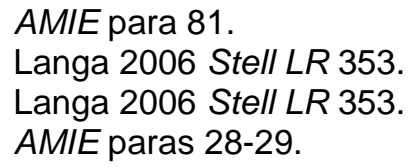


law proffered by the parties before the court, rather than the correct one. According to the SCA, both cases were presented by "agreement or concession" by the parties that the duration of the anti-dumping duty imposed by the Minister of Finance is a period of five years. ${ }^{85}$ This of course ignores the fact that the court in Progress Office Machines expressly held that the concessions by the litigants on duration were properly made. ${ }^{86}$ This assertion is ambiguous to say the least, but it implies that the court agrees with the litigants' legal submissions in that regard.

Furthermore, the court in AMIE goes so far as to say that the court in POM decided only the narrow question of what was meant by "imposition" in Article 11.3 and made the Order on that basis because that was what the parties agreed it should do. ${ }^{87} \mathrm{~A}$ court should not merely defer to the interpretation and shared views of the litigants before it, but must seek to find the correct legal position. It is the court's duty to interpret the law correctly and not to pander to the whims of the litigants. This subservient attitude of the SCA renders it a pawn for use by the colluding litigants and would leave interested parties uncertain as to the law on dumping in South Africa.

Pertinently, the bold and clear approach of the Constitutional Court in the SCAW case is correct in that the court did not merely defer to the litigants: it emphatically held that the Regulations echo the ADA when they provide that the dumping duties must expire after the five-year period has lapsed, unless a sunset review or a judicial review has been initiated prior to the said date of expiry. ${ }^{88}$ Thus, the flirtatious and yet non-committal approach of the SCA in POM and AMIE propagates the dreaded "indefinite inelastic term of duties" and promotes routine breaches of international obligations. ${ }^{89}$

\subsubsection{The Regulations}

In AMIE it was held that Progress Office Machines "decided nothing at all concerning the effects of the regulations". ${ }^{90}$ Contrary to this conclusion, the same court in Progress Office Machines emphatically held that Regulation 53, the gravamen of both cases, provides that anti-dumping

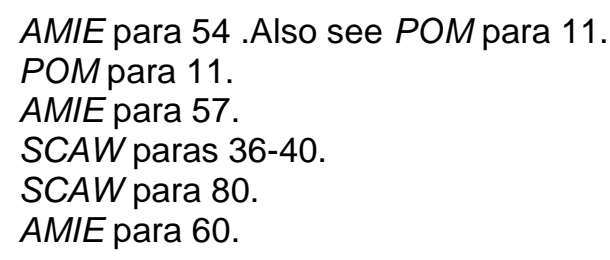


duties should not endure beyond the period of five years from the imposition or the date of the last review. ${ }^{91}$ In fact, Progress Office Machines held that the imposition of the duties beyond the five-year period demarcated in the ADA would be a breach of South Africa's international obligations and an unreasonable interpretation of the notice, and to that extent invalid. ${ }^{92}$ Thus, the SCA in the case of AMIE essentially attempts to rewrite its findings in the earlier judgment of Progress Office Machines.

Malan AJA, writing for the majority in Progress Office Machines, held that the court a quo was undoubtedly correct in finding that the anti-dumping duty may be imposed in certain circumstances for a period longer than five years. That is, where a sunset review has been initiated under Regulation 53.2 of the Anti-Dumping Regulations, the anti -dumping duty remains in force until the review has been finalised. ${ }^{93}$ In this regard Malan AJA implies that exceeding the five-year period is an exception rather than the norm. Consequently the court's dictum in AMIE that POM "decided nothing at all concerning the effects of the regulations" is incorrect. ${ }^{94}$ In fact, the decision in POM made more than a mere "passing reference" to the Regulations. ${ }^{95}$

\subsubsection{Ratification or not: The flirtatious and yet non-committal approach of the SCA}

In international law, ratification is the process by which a state deposits a document with a treaty depository signifying the state's definitive acceptance to be bound by the treaty which it has previously signed. ${ }^{96}$ The domestic process of "ratification" differs from state to state but typically involves some approval by a duly authorised legislative body, which gives the executive the right to ratify the treaty. Alternatively, it may bring the treaty provisions into municipal law to avoid conflict with the treaty obligations. ${ }^{97}$ In South Africa, the nature of the treaty determines whether it needs parliamentary approval or merely tabling. ${ }^{98}$

According to section 231 of the Constitution, an international agreement becomes law in SA only if it has been approved by resolution in the

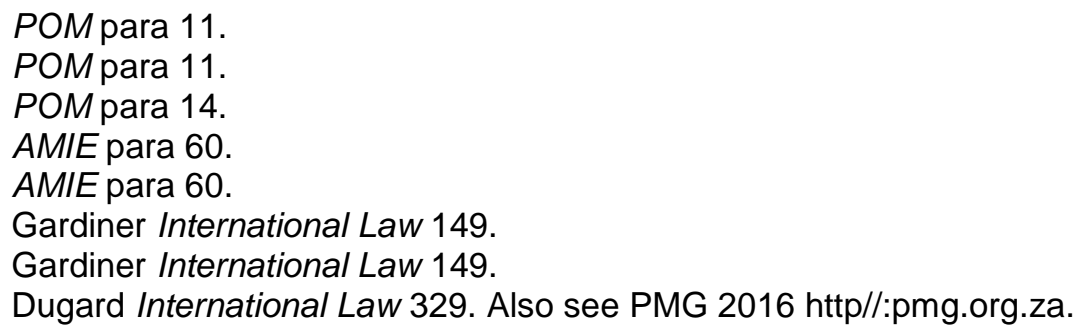


National Assembly and by the National Council of Provinces and when it is enacted into law by national legislation, unless it is an international agreement of a technical, administrative or executive nature, in which case it would not need approval by Parliament but must be tabled in the Assembly and Council within a reasonable time. ${ }^{99}$ Dugard believes that this approach of legislative enactment abandons the idealism of the Interim Constitution of 1993 and brings South African law into line with international law. ${ }^{100}$ Bearing this in mind, one can classify the ADA either as a "technical" treaty as per section 231(3) of the Constitution or an international agreement that requires approval by Parliament and legislative enactment as per section 231(2) and section 231(4) of the Constitution. Recent precedents on the ADA at the Supreme Court of Appeal and the Constitutional Court appear to gravitate towards the latter form, which requires parliamentary approval and legislative enactment. ${ }^{101}$

This approach should not detract from the contention that the ADA could be classified as a "technical" treaty as envisaged by section 231(3). This would negate the whole debate on ratification of the ADA and avoid the confusing judgments of the highest courts in South Africa on whether or not the ADA constitutes binding law in South Africa.

A study of recent precedents on the ADA in South African law is littered with ambiguity and confusion. The courts have vacillated between commitment and evasiveness on the relationship between the ADA and domestic law. The SCA, in Progress Office Machines, had held that the ITAA and the Anti-Dumping Regulations were "indicative" of an intention to give effect to the provisions of the treaties binding in the Republic in international law. ${ }^{102}$ It is not clear whether this equates to the enactment of the ADA into law by national legislation as per section 231 of the Constitution. It is contended that in practice, international treaties are approved and ratified but not incorporated into domestic law unless domestic implementation is essential for compliance with South Africa's international obligations. ${ }^{103}$ This current custom means that South Africa often becomes party to major treaties without incorporating them into

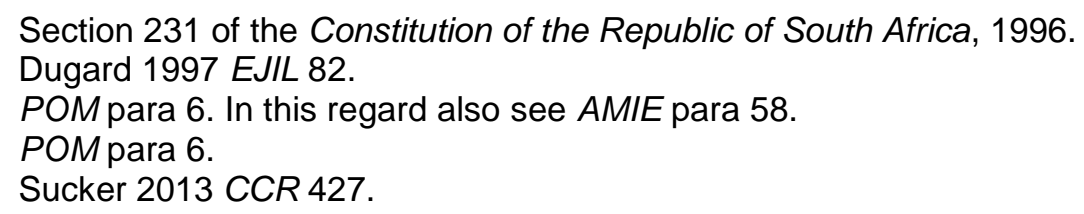


domestic law. ${ }^{104}$ This common sense approach would accord with the reasoning of the Constitutional Court in SCAW.

However, this assertion is in conflict with the Constitutional Court decision in Glenister $v$ the President of the Republic (hereafter Glenister), where it was held that the actions of the executive in negotiating and signing an international agreement do not result in a binding agreement. ${ }^{105}$ The court also held that legislative action is required before an international agreement can bind the Republic. ${ }^{106}$ Glenister held further that one of the methods of ratification is that the provisions of the agreement are embodied in the text of an Act. ${ }^{107}$ It is submitted that the CEA; the ITAA and the Regulations represent the "embodiment" of the provisions of the ADA on anti-dumping as contemplated in Glenister. Of course, it is not immediately clear what the term "embodiment" means. It could mean the comprehensive transplanting of a treaty into domestic law or the assimilation of the material terms of the international agreement, such as the ADA, into domestic law. The court in SCAW appeared to gravitate towards the latter form when it readily accepted that the ITAA, the Board on Tariffs and Trade Act 107 of 1986 and the Regulations were enacted to honour the ADA. ${ }^{108}$

In the same vein, the SCA in POM ironically held that the continuation of the anti-dumping duties in question would be a violation of the ADA and an unreasonable interpretation of the notice in casu. ${ }^{109}$ It further held that Article 11 of the ADA "obliges" South Africa to create a regime for the termination of anti-dumping duties and South Africa has "chosen" to do so via Regulations 38.1 and Regulation 53. ${ }^{110}$

However, the same court in AMIE held that the meaning attached to Article 11.3 of the ADA in its previous decision of Progress Office Machines is authoritative only when the Article is applied domestically but is immaterial in so far as this country's relations with its partners are concerned.111 In the same vein, yet paradoxically, the SCA in AMIE endorsed the decision in Progress Office Machines that the ADA does not

\footnotetext{
104 Sucker 2013 CCR 427.

105 Glenister v President of the Republic of South Africa 20113 SA 347 (CC) (hereafter Glenister) para 95.

106 Glenister para 95.

107 Glenister para 99.

108 SCAW para 2.

109 POM para 11.

110 AMIE paras 64-65.

111 AMIE para 82.
} 
apply directly in South African law. ${ }^{112}$ It is a perplexing feature of both judgments that the court appears to flirt with the ADA whenever convenient but never makes a commitment to it. This is even more astounding considering that the Constitutional Court's decision in SCAW was delivered in between the hearing of these two cases, and explicitly clarifies and establishes that the duration of a dumping duty in $S A$ is regulated by Article 11.3 of the ADA. ${ }^{113}$

The uncertainty created by $A M I E$ reflects the general confusion in SA law evident in the decision in Glenister. ${ }^{114}$ In Glenister the Constitutional Court was unable to definitively determine whether the Corruption Convention was approved by resolution of the National Assembly and the National Council of Provinces as required by section 231(2) of the Constitution. ${ }^{115}$ This is disappointing, to the say the least.

However, in SCAW the Constitutional Court explicitly held that South Africa's international obligations on tariffs and dumping arise from the ADA. ${ }^{116}$ As earlier stated, the Constitutional Court held that South Africa honours these obligations through the CEA, the Anti-Dumping Regulations, the ITAA and, where appropriate, the Board of Tariffs and Trade Act. ${ }^{117}$ Thus, SCAW endorsed the approach and the decision of Progress Office Machines with regards to the ratification of ADA in SA law in most respects. ${ }^{118}$ It was held in SCAW that a contrary approach would render the ADA nugatory and would impede the enforcement of the provisions of the ADA to the detriment of the member states, exporters and consumers. ${ }^{119}$ In $A M I E$, Wallis JA in a separate judgment also endorses SCAW's finding that South Africa's obligations under the ADA are binding. ${ }^{120} S C A W$, in its bold approach towards ratification, represents a step forward in advancing the common sense approach that the courts should not allow themselves to be constrained by the utopian rigours of black letter law, and endorses Dugard and Sucker's contention that current custom dictates that not all treaties have to be enacted into domestic law to become binding.

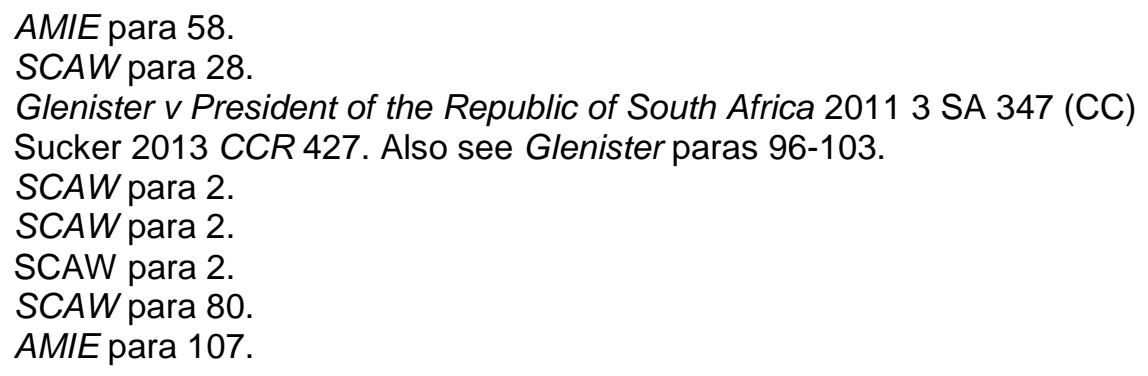


In any event, the Constitutional Court has held that international agreements that are not binding in our law may be used as interpretive tools. ${ }^{121}$ Thus, the AMIE decision on the question of the direct application of the $A D A$ in South African law appears to contradict the Constitutional Court's finding in SCAW and thus represents a flagrant disregard of the doctrine of stare decisis which binds the South African courts to follow the decisions of the Constitutional Court as the highest court in South Africa.

Furthermore, the AMIE decision that POM did not endorse Article $11.3^{122}$ is disconcerting. Firstly, there is no cogent reason for a court to permit litigants to proceed on legal grounds emanating from legislation that it deems inapplicable to South African law. Secondly, if Article 11.3 of the ADA creates no rights as held in $P O M,{ }^{123}$ one is perplexed by Malan AJA's conclusion in the same case that section 59 of ITAA seeks to give effect to the ADA. ${ }^{124}$

Moreover, the ITAA provides that the object of the CEA is to create the ITAC, whose principal duty is to carry out the functions that arise out of an obligation of the Republic in terms of a trade agreement, if the Minister has assigned that function to the Commission. ${ }^{125}$ This represents a clear and emphatic intention to honour trade agreements like the ADA and to ratify the ADA, as seen by the various provisions in the CEA and Regulations that are borrowed from the WTO Agreements. The court in Progress Office Machines concurred with this conclusion. ${ }^{126}$ Furthermore, in Chairman: Board On Tariffs and Trade $v$ Brenco Incorporated it was held that the Board of Tariffs and Trade had been guided by the Anti-Dumping Agreement in drafting the dumping legislation. ${ }^{127}$

Thus, the SCA's and the Constitutional Court's flirtatious and yet noncommittal approach to the ADA creates an environment of uncertainty. South Africa is yet to promulgate legislation that explicitly reflects ratification of ADA, but the CEA, the ITAA and the Regulations reflect an implicit attempt at ratification. A slavish adherence to the orthodox method of ratifying an international treaty would be superficial and would place an unfair financial burden on countries seeking to export goods to SA. This

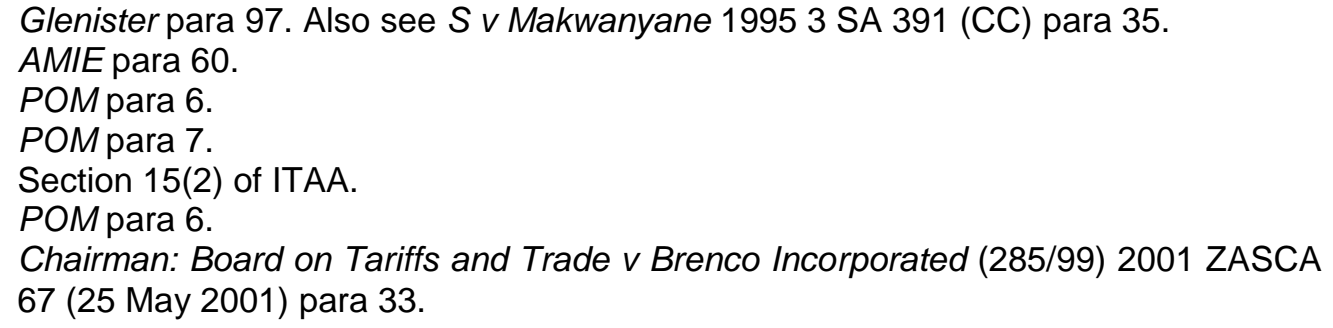


approach is endorsed by Dugard, who submits that ratification depends on intention. ${ }^{128}$ Dugard submits that when parties intend that a treaty is to come into force immediately, it would be ridiculous for South African courts to insist on parliamentary ratification. ${ }^{129}$ In any event, the anti-dumping duties are imposed against products from other countries and not domestic products. The effect of the court decisions is international because the effects of the duty are directly felt by companies exporting goods to South Africa, as held by the Constitutional Court in the SCAW case. $^{130}$

In addition, the ADA expressly provides for judicial, arbitral or administrative tribunals or procedures for the purpose, inter alia, of the prompt review of administrative actions relating to final determinations in duties. ${ }^{131}$ This enables the national judicial review of anti-dumping duties imposed against products from other WTO member countries. Therefore, there is no doubt that the decisions passed by national courts on a WTO issue have an international application and are recognised by the WTO. Moreover, the ADA expressly confers upon ITAC, upon its own initiative or that of affected parties, the right to review the anti-dumping duties which affect products from other countries. ${ }^{132}$ Member countries are granted the right to decide either continue with the duties or to terminate. ${ }^{133}$ This power is conferred on national bodies and not international bodies. These decisions have effects beyond national borders. In the same vein, the DSU specifically confers upon any nation that has legislation on antidumping to allow judicial review in terms of Article 13 of anti-dumping duties.

In fact, endorsement of the continued imposition of duties on chicken portions in $A M I E$ has led to a protracted legal dispute between South Africa and the United States of America, which has culminated in the latter threatening to retaliate against South Africa through the removal of preferences granted to South Africa under the Africa Growth Opportunity Act (AGOA).This threat of retaliation clearly shows that the absurd conclusion in AMIE that the SCA's decisions on dumping are not material to South Africa's relations with other countries is unsound and devoid of merit.

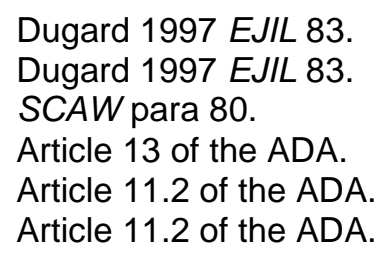




\section{Conclusion}

It appears that international trade law disputes will continue to be decided according to the law as interpreted by the litigants and not the courts. This is because the courts have proven malleable to the claims of the litigants on disputes pertaining to dumping and have permitted them to proceed on grounds which may or may not have legal merit.

Secondly, there is considerable uncertainty on whether the ADA is binding in South African law or not. The courts in South Africa seem ill equipped to deal with international trade law disputes. This may be an unintended consequence of the general malaise of African countries in WTO disputes and their insipid reluctance to engage other nations in trade disputes due to shortages in skill and financial resources. This unfortunate economic consequence and the paucity of African precedents in the WTO dispute resolution process may have seeped into the South African courts and led to general uncertainty on dumping law.

Despite valiant attempts by the SCA and the Constitutional Court to develop cogent legal solutions to the question of the correct methodology to use in order to determine the date of the commencement of definitive anti-dumping duties, particularly when provisional measures are concerned, the courts have failed to create legal certainty in this area. The ambivalence of the highest courts in South Africa has morphed into a flirtatious and non-committal approach to issues relating to dumping law. This has happened despite the Constitutional Court's attempts to bring clarity to the issue.

The newly minted CDA, with its deliberately selected simpler terminology and precise provisions derived from international law on the method of determining the date of imposition of anti-dumping duties, particularly where provisional duties are involved, may bring clarity and cogency to the South African situation and also align South African law on dumping with WTO law. 


\section{Bibliography}

\section{Literature}

Brink 2008 De Jure

Brink G "Progress Office Machines v South African Revenue Services Case [2007] SCA 118 (RSA)" 2008 De Jure 643-648

Dugard 1997 EJIL

Dugard J "International Law and the South African Constitution" 1997 EJIL 77-92

Dugard International Law

Dugard J International Law: A South African Perspective $2^{\text {nd }}$ ed (Juta Kenwyn 2000)

Gardiner International Law

Gardiner K International Law (Pearson Longman London 2003)

Langa 2006 Stell LR

Langa P "Transformative Constitutionalism" 2006 Stell LR 351-360

Ndlovu 2013 SAPL

Ndlovu L "South Africa and the World Trade Organisation Anti-Dumping Agreement Nineteen Years into Democracy" 2013 SAPL 279-307

Sucker 2013 CCR

Sucker $\mathrm{F}$ "Approval of an International Treaty in Parliament: How Does Section 231(2) 'Bind the Republic'?" 2013 CCR 417-434

\section{Case law}

Association of Meat Importers v ITAC 20134 All SA 253 (SCA)

Chairman: Board on Tariffs and Trade v Brenco Incorporated (285/99) 2001 ZASCA 67 (25 May 2001)

Glenister v President of the Republic of South Africa 20113 SA 347 (CC)

International Trade Administration Commission v SCAW South Africa (Pty) Ltd 20124 SA 618 (CC)

Progress Office Machines v SARS 20082 SA 13 (SCA)

S v Makwanyane 19953 SA 391 (CC) 


\section{Legislation}

Board of Tariffs and Trade Act 107 of 1986

Constitution of the Republic of South Africa, 1996

Customs and Excise Act 91 of 1964

Customs Duty Act 30 of 2014

International Trade Administration Act 71 of 2002

\section{International instruments}

Agreement on the Implementation of Article VI of the General Agreement on Tariffs and Trade (1994) (Anti-Dumping Agreement)

General Agreement on Tariffs and Trade (1994)

\section{Government Publications}

GN 3197 in GG 25684 of 14 November 2003 (International Trade Administration Commission Regulations on Anti-Dumping in South Africa)

GN 1606 in GG 29382 of 10 November 2006

\section{Internet sources}

Brink 2006 http://tinyurl.com/j6472zr

Brink G 2006 Proposed Amendments to the Anti-dumping Regulations: Are the Amendments in Order? http://tinyurl.com/j6472zr accessed 10 May 2015

Brink 2012 http://tinyurl.com/zk633kd

Brink G 2012 Anti-dumping in South Africa http://tinyurl.com/zk633kd accessed 10 May 2015

PMG 2016 http://pmg.org.za

Parliamentary Monitoring Group 2016 Process for International Agreements in South Africa http://pmg.org.za accessed 19 February 2016

SARS $2015 \mathrm{http}: / /$ www.sars.gov.za

South African Revenue Service 2015 New Customs Legislation Update http://www.sars.gov.za accessed 16 May 2016 
WTO $2001 \mathrm{http}: / /$ tinyurl.com/gwkfrmf

World Trade Organisation 2001 Dispute Settlement: Dispute DS132 Mexico - Anti-Dumping Investigation of High-Fructose Corn Syrup (HFCS) from the United States http://tinyurl.com/gwkfrmf accessed 19 February 2016

\section{List of abbreviations}

$\begin{array}{ll}\text { ADA } & \text { Anti-Dumping Agreement } \\ \text { AGOA } & \text { Africa Growth Opportunity Act } \\ \text { AMIE } & \text { Association of Meat Importers and Exporters } \\ \text { CCR } & \text { Constitutional Court Review } \\ \text { CDA } & \text { Customs Duty Act } \\ \text { CEA } & \text { Customs and Excise Act } \\ \text { DSU } & \text { Dispute Settlement Understanding } \\ \text { EJIL } & \text { European Journal of International Law } \\ \text { GATT } & \text { General Agreement on Tariffs and Trade } \\ \text { ITAA } & \text { International Trade Administration Act } \\ \text { ITAC } & \text { International Trade Administration Commission } \\ \text { PMG } & \text { Parliamentary Monitoring Group } \\ \text { POM } & \text { Progress Office Machines } \\ \text { SAPL } & \text { Southern Africa Public Law } \\ \text { SARS } & \text { South African Revenue Service } \\ \text { SCA } & \text { Supreme Court of Appeal } \\ \text { Stell LR } & \text { Stellenbosch Law Review } \\ \text { WTO } & \text { World Trade Organisation }\end{array}$

